\title{
A meridional profile of the chemical composition of submicrometre particles over the East Atlantic Ocean: regional and hemispheric variabilities
}

\author{
By C. LECK $^{1 *}$, J. HEINTZENBERG ${ }^{2}$ and M. ENGARDT ${ }^{3}$, ${ }^{1}$ Department of Meteorology, Stockholm \\ University, S-10691 Stockholm, Sweden; ${ }^{2}$ Institute for Tropospheric Research, Permoserstr. 15, D-04318 \\ Leipzig, Germany; ${ }^{3}$ Swedish Meteorological and Hydrological Institute, S-601 76 Norrköping, Sweden
}

(Manuscript received 18 May 2001; in final form 18 April 2002)

\begin{abstract}
Within the framework of SWEDARP (Swedish Antarctic Program) 92/93 an aerosol sampling program was carried out on board of $\mathrm{M} / \mathrm{S}$ Polarbjörn which carried staff and material to the Nordic Antarctic field exercises during the Austral summer 1992/1993. The cruise started 11 November 1992 from Oslo, went via Cape Town to Antarctica, and then back to Cape Town where the ship arrived on 4 January 1993. During the cruise, a meridional profile of physical and chemical submicrometre aerosol properties was derived covering the East Atlantic Ocean from $60^{\circ} \mathrm{N}$ to $70^{\circ} \mathrm{S}$. The multicomponent aerosol data set combined with a trajectory analysis revealed a systematic meridional distribution of aerosol sources over the Atlantic that covered European and African continental plumes and, south of $15^{\circ} \mathrm{S}$, a largely biologically controlled marine aerosol. Median number concentrations calculated over the whole cruise spanned a factor of 20 between 2000 and $100 \mathrm{~cm}^{-3}$, while total analyzed mass concentrations ranged between 7800 and $40 \mathrm{ng} \mathrm{m}^{3}$. From the biologically dominated subset of the data in the southern hemisphere, relationships were developed that allowed an apportionment of the observed sulfate and ammonium concentration to biogenic and anthropogenic sources over the whole meridional aerosol profile.
\end{abstract}

\section{Introduction}

The renewed interest in the global distribution of atmospheric aerosols and their effects has been stimulated by their incorporation into global chemical transport models (CTM) (Langner and Rodhe, 1991). The ensuing studies of their climate forcing (Charlson et al., 1991; Kiehl and Rodhe, 1995; Kiehl et al., 1999; Kiehl et al 2000; Liousse et al., 1996; Penner, 1995; Penner et al., 1992) and the climate response with global circulation models (GCM) (Roeckner et al., 1995; Taylor and Penner, 1994) and climate statistics (Engardt and

\footnotetext{
* Corresponding author e-mail: lina@misu.su.se
}

Rodhe, 1993; Karl et al., 1995) lead to the widely accepted notion that the understanding of the atmospheric aerosol is of high value for climate change research. The models generate (or use) monthly, seasonal or annual mean maps of global distributions of aerosol components.

The value of these theoretical studies is limited by the sparseness of detailed global experimental aerosol data. Whereas CTM exercises often report zonal mean aerosol-related quantities they do not employ related aerosol information which has been derived in meridional marine profiling studies covering both hemispheres in order to validate the model results.

Since the cruise of the R.V. Meteor in 1969 (Junge and Jaenicke, 1971), many marine aerosol 
experiments have derived extended meridional profiles of aerosol composition and properties as reviewed in Heintzenberg et al. (2000). Many of the older cruise data were derived without sample control by condensation particle counters and without well defined inlet characteristics of the respective particle samplers. Thus, the results of these studies must be used with care. The present report extends the series of meridional interhemispheric aerosol studies with data on concentrations and source identification of submicrometre aerosol components. By a synopsis of the present data set with reported annual average meridional profiles, we point out the value of such data for the validation of global aerosol models.

\section{Experimental}

\subsection{Sampling and real time measurements}

M/S Polarbjörn was used as a ship of opportunity to gather data for a meridional profile of aerosol number and composition. The cruise track is shown in Fig. 1 along with a composite of $5 \mathrm{~d}$ of back trajectories (discussed in more detail in
Section 3). A cyclone inlet was deployed at ambient conditions to eliminate particles with diameters larger than $1 \mu \mathrm{m}$ from the sampling train. The inlet was located forward $12 \mathrm{~m}$ above sea level. As the ship's course and operations were not optimized for aerosol sampling, measures had to be taken to minimize the risk of selfcontamination from the combustion source of the vessel. For that purpose, the samplers were controlled by a condensation particle counter (CPC, TSI Inc, model 7610) connected via a microprocessor controller (CPCC) to the sampling pumps (Ogren and Heintzenberg, 1990). The CPCC also processed the CPC signals for the recording of 10-min averages on a personal computer. The CPC counts particles between $15 \mathrm{~nm}$ and the size cut of the cyclone inlet (Noone and Hansson, 1990), which was $1 \mu \mathrm{m}$ for the present study. Figure 2 gives a schematic overview of the sampling system.

Depending on the expected ambient mass concentrations, duplicate Nuclepore ${ }^{\circledR}$ filter samples were taken for 24 or $48 \mathrm{~h}$ on $0.4 \mu \mathrm{m}$ pore size $37 \mathrm{~mm}$ diameter filter disks masked to $8 \mathrm{~mm}$ sampling diameter to optimize the analytical condi-

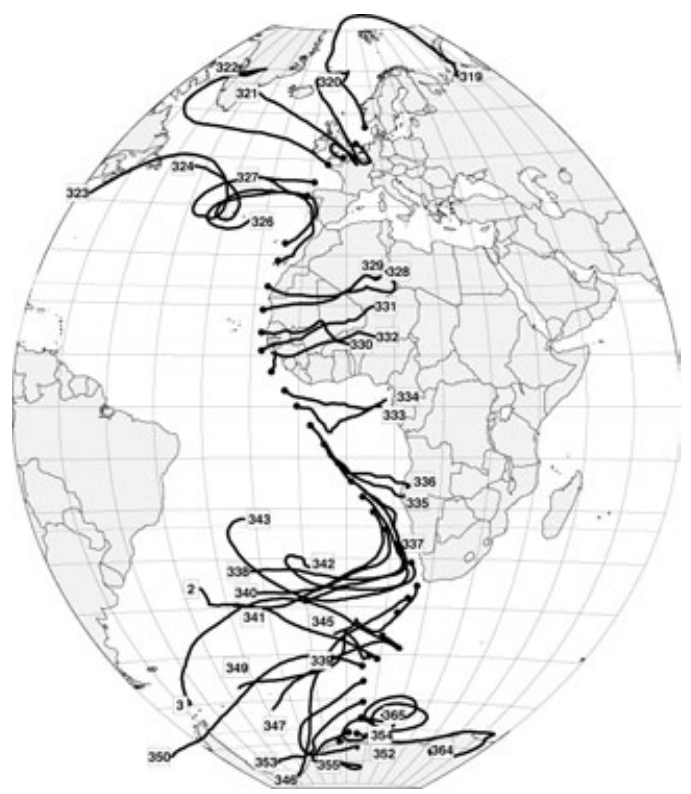

\begin{tabular}{|c|l|}
\hline DOY & \multicolumn{1}{|c|}{ REGION } \\
\hline $319-320$ & Polar Arctic Ocean \\
\hline $320-321$ & North Sea, English Channel, polluted \\
\hline 321 & North Sea, English Channel, less polluted \\
\hline $323-326$ & Mid-latitude North Atlantic, less polluted \\
\hline $326-328$ & Mid-latitude North Atlantic High, polluted \\
\hline $328-330$ & North Atlantic Ocean, Sahara \\
\hline $330-334$ & Central Atlantic Ocean, Tropical Africa \\
\hline $335-338$ & Mid-latitude South Atlantic, polluted \\
\hline $340-343$ & Mid-latitude South Atlantic High, less polluted \\
\hline $345-348$ & Mid-latitude South Atlantic semi High, clean \\
\hline $349-365$ & Southern Ocean \\
$1-3$ & \\
\hline $351-365$ & Southern Ocean, Antarctica ice shelf \\
\hline
\end{tabular}

Fig. 1. Selected sampling locations and 5-d back trajectories during the sampling cruise Oslo-Antarctica-Cape Town, 11 November 1992 to 4 January 1993. Air mass regions with corresponding day-of-year (DOY) are given in the table. 


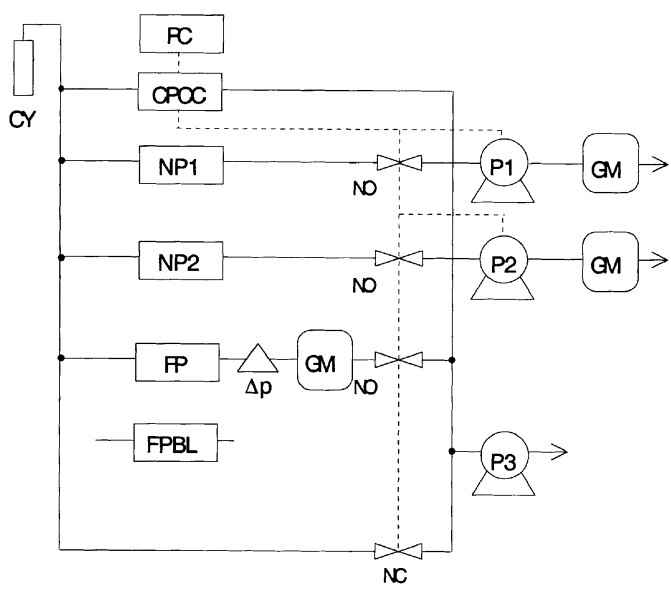

Fig. 2. The sampling system. CPCC, condensation particle counter/controller; CY, $1 \mu \mathrm{m}$ cut diameter cyclone GM, dry gas meter; NC, mormally closed; NO, normally open; FP, filter pack; FPBL, filter pack blank; NP1/2, masked Nuclepore ${ }^{\circledR}$ filters; PC, personal computer; P1-P3 pumps; $\triangle \mathrm{p}$, differential pressure meter. Solid lines denote the air flow, dashed lines represent electrical signals.

tions for the particle analyses (Hansson et al., 1986). On filter packs (FP) 6-9 h samples were taken. For collection we used two FP units (one serving as field blank, FPBL), consisting of one $47 \mathrm{~mm}$ Millipore Teflon aerosol particle filter with $1.0 \mu \mathrm{m}$ pore size (flow rate 50 standard litre per min; slpm) held in a polyacetal Delrin filter holder. For each of the sampling trains the air volumes were determined with dry gas meters. The reading of the gas meter of the FP (operating at reduced pressure) was corrected with a differential pressure meter. In order to flush the sampling stack during off-periods the main pump (P3) operated through a bypass during periods of contamination.

\subsection{Aerosol particle sampling and analyses}

2.2.1. Filter pack samples. After the sampling, the filter pack filters were stored in centrifuge tubes made of polystyrene after wetting them with $0.5 \mathrm{~cm}^{3}$ methanol. The tubes were closed with polypropylene caps, which were sealed with Para film. Until further treatment at the laboratory in Stockholm in January 1993, they were stored at $1{ }^{\circ} \mathrm{C}$. The Nuclepore ${ }^{\circledR}$ filters were stored in the filter cassettes, which were locked with Para film.
Back at the Stockholm laboratory, inside a glove box (free from particles, sulfur dioxide and ammonia), the filter substrates were extracted (in centrifuge tubes) by first wetting with $0.5 \mathrm{~cm}^{3}$ methanol, then adding $4.5 \mathrm{~cm}^{3}$ deionized water. Finally, the filter solutions were sonicated for $60 \mathrm{~min}$. The extracts were then analyzed for major cations, and major and weak anions by chemically suppressed ion chromatography (IC).

The analysis of cations was made with a Dionex CG12A/CS12A column and a CSRS-I autosuppressor, with external water mode (Dionex Corporation), $20 \mathrm{mM}$ MSA eluent (flow $1 \mathrm{~cm}^{3} \mathrm{~min}^{-1}$ ), and water as suppressor regenerant. Total analysis time was $15 \mathrm{~min}$. Strong anions were analyzed with a Dionex AG4A/AS4A column and an ASRS-I auto-suppressor with external water mode, $1.8 \mathrm{mM} \mathrm{NaHCO} 3 / 1.7 \mathrm{mM} \mathrm{Na}_{2} \mathrm{CO}_{3}$ $\left(2 \mathrm{~cm}^{3} \mathrm{~min}^{-1}\right)$, and water as suppressor regenerant. The analysis time was $8 \mathrm{~min}$.

Weak anions were analyzed with a Dionex AG4/AS4 column and an ASRS-I auto-suppressor with external water mode, water being used as the regenerant. For optimal separation of weak organic ions such as formate, acetate, pyruvate and methane sulfonate (MSA), and to elute strongly retained anions in the column, a $5 \mathrm{mM}$ $\mathrm{NaOH}$ mobile phase was used for $8 \mathrm{~min}$, followed by $100 \mathrm{mM} \mathrm{NaOH}$ for $5 \mathrm{~min}$, and then a reset to $5 \mathrm{mM} \mathrm{NaOH}$ for $10 \mathrm{~min}$. The total analysis time was $23 \mathrm{~min}$, with an eluent flow of $1.5 \mathrm{~cm}^{3} \mathrm{~min}^{-1}$. Before preparing the $\mathrm{NaOH}$ eluents, deionized water was degassed using $99.995 \%$ purified helium in order to minimize the formation of $\mathrm{Na}_{2} \mathrm{CO}_{3}$ caused by the uptake of carbon dioxide. A Dionex ATC-1 column was used before the injection valve in order to retain carbonate and other ionic contaminants in the eluent during the run. Under our analytical conditions, the MSA retention time is about $8 \mathrm{~min}$ and is well resolved from pyruvate.

For the analyses of anions and cations, a $25 \mu^{3}$ sample was injected. For the weak anion analysis, the corresponding sample volume was $1 \mathrm{~cm}^{3}$. The precision given within one standard deviation as percentage of the mean value, in the anion, cation and weak anion analyses was better than $\pm 1 \%$, $\pm 2.5 \%$ and $\pm 2 \%$, respectively. The analytical detection limits required for the various ions, defined as twice the level of peak-to-peak instrument noise, were $0.20,0.05,0.10,0.01,0.01,0.25$, $0.02,0.01$, and $0.001 \mu \mathrm{eq} \mathrm{dm}-3$, for sodium $\left(\mathrm{Na}^{+}\right)$, 
ammonium $\left(\mathrm{NH}_{4}^{+}\right)$, potassium $\left(\mathrm{K}^{+}\right)$, magnesium $\left(\mathrm{Mg}^{2+}\right)$, calcium $\left(\mathrm{Ca}^{2+}\right)$, and chloride $\left(\mathrm{Cl}^{-}\right)$, nitrate $\left(\mathrm{NO}_{3}^{-}\right)$, sulfate $\left(\mathrm{SO}_{4}^{2-}\right)$, and MSA, respectively.

Each set of duplicate samples was individually blank-corrected. Non-sea-salt (nss)-SO $\mathrm{SO}_{4}^{2-}$ concentrations were calculated by using sodium concentrations and seawater composition taken from Wilson (1975). The sea-salt contribution was on average less than $5 \%$ of the total submicrometre $\mathrm{SO}_{4}^{2-}$ concentrations.

2.2.2. Nuclepore ${ }^{\circledR}$ filter samples. On both sets of Nuclepore ${ }^{\circledR}$ filters (NP1 and NP2), elements with mass numbers larger than 12 were analyzed by means of particle induced X-ray emissions (PIXE) at the Department of Nuclear Physics, Lund University (Johansson et al., 1970). Complementing the IC analyses PIXE yields information about crustal components such as silicate $(\mathrm{Si})$, aluminium $(\mathrm{Al})$, and iron $(\mathrm{Fe})$ and anthropogenic components such as vanadium (V).

On masked Nuclepore ${ }^{\circledR}$ filters of the sampling train NP2 we analyzed elemental carbon (EC) with the soot photometer described in Heintzenberg (1988). It is based on the absorption of visible light (wavelength $\lambda=0.55 \mu \mathrm{m}$ ) and thus, non-specific for EC. Near combustion sources, EC is the dominating light absorber in the atmospheric aerosol. However, high amounts of crustal material in the samples such as taken in the Saharan region cause significant light absorption. The most important crustal absorbers are the metal oxides. Amongst those, hematite $\left(\alpha-\mathrm{Fe}_{2} \mathrm{O}_{3}\right)$ is thought to have the highest light absorption in the visible spectral region. The imaginary part $\mathrm{K}$ of the refractive index is the critical parameter when comparing competing absorbers in an aerosol sample. For hematite hydrosols with diameters less than $0.02 \mu \mathrm{m}$ Kerker et al. (1979) derived a value of 0.065 for $\mathrm{K}_{0.55}$ near $\lambda=0.55 \mu \mathrm{m}$. Derived from Kubelka-Munk analysis Gillespie and Lindberg (1992) reported a corresponding value of $\mathrm{K}_{0.55}=0.5$ for hematite particles with diameters less than $40 \mu \mathrm{m}$ embedded in a highly reflective (very weakly absorbing) powder. Intermediate values of $\mathrm{K}_{0.55}$ have been reported by other authors (cf. the review in Kerker et al., 1979). We consider the coarse particle results of Gillespie and Lindberg to be more appropriate for an EC correction in the Saharan region. The iron content measured in the same samples can be used in a procedure described in Heintzenberg (1982) to derive an upper limit for the crustal signal in the soot photometer. In this approach, all measured iron is assumed to exist in the form of hematite $\left(\alpha-\mathrm{Fe}_{2} \mathrm{O}_{3}\right)$ having $\mathrm{K}_{0.55}=0.5$. With this molecular form, iron concentrations need to be multiplied by 2.86 to yield hypothetical hematite concentrations. This number has to be related to the corresponding value for EC. Again, there is a range of imaginary parts of the refractive index for EC in the literature spanning more than a factor of two. Adopting the frequently used value $\mathrm{K}_{0.55}=0.5$ for EC we may treat the two materials on a massequivalent basis. Thus, we subtracted $2.86 \times \mathrm{Fe}$ concentrations from the apparent EC data. In the samples with the highest crustal signals, this correction leads to negative concentrations, which we interpret as being a consequence of our worstcase assumption about the crustal influence. The non-sea salt non-crustal potassium component $\left(\mathrm{K}_{\mathrm{nssncr}}\right)$ was calculated by first subtracting the sea salt potassium by using sodium and average sea water composition according to Wilson (1975) and then subtracting crustal potassium by using crustal calcium from measured calcium and the average crustal composition (Taylor, 1964). Noncrustal vanadium $\left(\mathrm{V}_{\mathrm{ncr}}\right)$ was calculated by subtracting the crustal contribution of $\mathrm{V}$ with the analyzed aluminium concentrations and the average crustal composition according to Taylor (1964).

In Tables 1 and 2 we have tabulated the value for each substance for all measurements during OEA-92. All atmospheric particulate data are expressed in mol per $\mathrm{m}^{3}$ for the temperature $293.15 \mathrm{~K}$ and for the pressure $1013.25 \mathrm{hPa}$, such that $1 \mathrm{nmol} \mathrm{m}^{-3}=24.5 \mathrm{ppt}(\mathrm{v})$.

\subsection{Supporting data}

Meteorological observations were made at 3-h intervals in which position, temperature, pressure, wind, visibility and cloudiness were recorded manually. The history of each of the air masses sampled was derived from five-day threedimensional (3D) backward trajectories, reaching the ship's position and pressure level at 00, 06, 12, and $18 \mathrm{~h}$ UTC. The trajectories were calculated with the 1991 version of McGrath's trajectory 
model (McGrath, 1989), using the analyzed horizontal and vertical wind components of the European Center for Medium Range Weather Forecasts.

\section{Route and meteorological overview}

The cruise and the measurement program started near $60^{\circ} \mathrm{N}$ in Oslo, Norway, continued across the equator, via Cape Town, South Africa, at $34^{\circ} \mathrm{S}$, to the Antarctic coast at $70^{\circ} \mathrm{S}$, before the measurement program was finally terminated at Cape Town on the homebound leg of $\mathrm{M} / \mathrm{S}$ Polarjörn. The route went through the eastern Atlantic Ocean and passed through various climate zones spanning the period 11 November 1992 (day-of-year, DOY 316) through 4 January 1993 (DOY 4). In the following, the different characteristics of the air masses sampled are classified and then discussed to aid the interpretation of the aerosol data. For this purpose, we use the calculated 3D 5-d arrival trajectories as exemplified in Fig. 1. Additionally, on board meteorological observations and the meteorological maps issued by the German Weather Service were used.

During the first few days (DOY 316-320) the temperature was generally below $10{ }^{\circ} \mathrm{C}$ and the air mass was classified as Polar Arctic Ocean from the arrival trajectories. For most of the time, the sky was overcast with low clouds, but no local precipitation.

During DOY 320-321, the general transport direction was still from the northern Atlantic. Sampling took place in the highly trafficked waters of the North Sea and the English Channel. Prior to sampling, the air also had passed over the British Isles; therefore, this period was classified as North Sea, English Channel, polluted. This period was also characterised by overcast sky with low clouds with visibilities often below $10 \mathrm{~km}$.

On the morning of DOY 321 precipitation was reported on board the ship, in connection with a frontal passage, accompanied by wind speeds over $20 \mathrm{~m} \mathrm{~s}^{-1}$. The storm lasted until the afternoon of DOY 322. It was classified as North Sea, English Channel, less polluted.

Although no precipitation was observed locally from mid DOY 322 through DOY 325, the air arriving at the ship frequently had passed through precipitating frontal systems further out in the ocean. Thus, we classified this period as Midlatitude North Atlantic, less polluted.

Around noon of DOY 326, the temperature rose rather abruptly from 18 to $22^{\circ} \mathrm{C}$. According to the weather charts, the ship entered a different weather regime with anticyclonic circulation, which was accompanied by subsiding air inhibiting wet scavenging. The trajectories also indicated possible land contact of the air prior to arrival at the ship (cf. Fig. 1). During DOY 326-328, the pathway of the air masses suggests that anthropogenic pollutants were picked up over the Iberian Peninsula and Morocco. Consequently, this period was classified as Mid-latitude North Atlantic High, polluted.

From DOY 328 through DOY 330 mainly continental air was sampled. The local temperature was well above $20^{\circ} \mathrm{C}$ and easterly winds prevailed. The period termed North Atlantic Ocean, Sahara was spent in air masses that were heavily influenced by the Saharan dust region with 5-d trajectories extending nearly to the centre of the arid area, indicating persistent transport conditions.

Days DOY 331 through 334 were spent in the equatorial trough with the highest temperatures encountered during the cruise. In the beginning of the period (DOY 331-332), the sampled air had passed more frequently over highly populated savannah and forested areas, thus increasing the possibility of anthropogenic influence. Part of the sampled air was also influenced by the Sahel dust region. Towards the end of the period (DOY 333-334) and according to the back trajectories, the sampled air had characteristics of equatorial waters and of tropical Africa. This part of Africa is characterised by evergreen tropical rainforest, although there was probably only little rain over the continent in late November and early December, when the African monsoon brought continental air out over the Gulf of Guinea. This period was labelled Central Atlantic Ocean, Tropical Africa.

From DOY 334 on, the ship moved into the subtropical high-pressure zone of the southern hemisphere. The period DOY 335-338 was spent in air that carried some continental characteristics besides considerable oceanic influence. The continental influence came from the semi-arid regions of Angola and Namibia. This period is denoted Midlatitude South Atlantic, polluted. 
During DOY 339-343 less polluted oceanic air was encountered in the southern hemisphere subtropical high-pressure zone. This period was classified Mid-latitude South Atlantic High, less polluted.

After a stop in Cape Town during DOY 343, $\mathrm{M} / \mathrm{S}$ Polarbjörn continued her cruise in oceanic air, gradually leaving the stagnant and subsiding air masses of the subtropical high-pressure zone in order to enter the west wind belt of the southern ocean. The period DOY 345-348 was characterised by persistent but relatively weak winds from south west but with relatively weak frontal activity. The label of this period is Mid-latitude South Atlantic semi-High, clean.

From DOY 349 through $353 \mathrm{M} / \mathrm{S}$ Polarbjörn encountered several frontal passages with corresponding precipitation and high wind speeds. The sky was almost continually covered by $100 \%$ lowlevel stratus. The period DOY 348-351 plus days 1-3 of 1993 on the way back to Cape Town are termed Southern Ocean.

The first icebergs were encountered at DOY 348 , and the ship entered a more complete ice cover on DOY 354. From DOY 352 through DOY 366 the sampled air had some characteristics of the partly ice-free waters surrounding the Antarctic continent, including the highly productive leads and ice-edge. Frequently, the air arriving at M/S Polarbjörn also had been in contact with the Antarctic continent. The latter period is called Southern Ocean, Antarctica ice shelf.

\section{Meridional aerosol profiles}

\subsection{Continental aerosol components}

The meridional profiles of particle number and all chemical sample data are collected in Tables 1 and 2. As a quality check of the present study, the meridional aerosol profiles will be compared below to annual average reference aerosol data from North and South Atlantic (AAA). For $15^{\circ}$ latitude bins and for the longitude range $75^{\circ} \mathrm{W}$ to $20^{\circ} \mathrm{E}$ these reference data were extracted from the marine aerosol database underlying the review and compilation of Heintzenberg et al. (2000). We note specifically that this marine database also comprises the aerosol data covering most of the present geographical region, which have been taken by Davison et al. during a voyage of the
British research vessel RRS Bransfield during the same period as the present study (Davison et al., 1996a; Davison et al., 1996b). Whenever direct comparisons are possible, the results of Davison et al. will be discussed explicitly.

A source-related selection of the present study's aerosol parameters is displayed in Fig. 3 over the latitudinal range from $60^{\circ} \mathrm{N}$ to $20^{\circ} \mathrm{S}$. As thick horizontal bars, the annual average reference data are displayed as well. Missing reference bars indicate where the present study filled data gaps in the marine aerosol database.

Median number concentrations calculated over the whole cruise spanned a factor of 50 between 2000 and $40 \mathrm{~cm}^{-3}$, while total analyzed mass concentrations ranged between 7800 and $40 \mathrm{ng} \mathrm{m}^{-3}$. In general, the particle numbers of the present cruise lie near the respective annual average values (Heintzenberg et al., 2000). The major exception at latitudes north of $45^{\circ} \mathrm{N}$ is due to the average Atlantic numbers not including data from the highly polluted European region as experienced on the present cruise en route from Oslo to the Gulf of Biscay. The same explanation holds for the large mid-latitude difference between annual average EC concentrations and the EC data of the present study (cf. Fig. 3c).

With the exception of biogenic sulfur, the largest regional source-related variabilities occurred within the latitude band from $60^{\circ} \mathrm{N}$ to $20^{\circ} \mathrm{S}$. This band comprises anthropogenic aerosol source regions, i.e. the industrial mid-latitude areas of North America and Europe, the populated western parts of northern and central Africa and the seasonally important African biomass burning regions. In addition, the complete trade wind related Saharan dust plume stands out as a major natural aerosol feature in this latitude band.

Regional anthropogenic aerosol sources are reflected in the CPC signal, with three peaks between $50^{\circ} \mathrm{N}$ and $20^{\circ} \mathrm{N}$ and one peak in the region between $10^{\circ} \mathrm{N}$ and the equator (cf. Fig. 3a). The chemical analyses reveal more source-related details. In particular, nss- $\mathrm{SO}_{4}^{2-}, \mathrm{V}$, and $\mathrm{EC}$ are tracers of combustion-related aerosols. Vanadium is a sensitive tracer for oil combustion (Rahn, 1976). The major peaks of vanadium mass concentrations coincide with three major CPC peaks and indicate areas of fossil fuel combustion around 53, 45,27 , and $10^{\circ} \mathrm{N}$, labeled A1-A4. Figure 3a shows that the present study filled several gaps in the 
Table 1. Concentration $\left(\mathrm{nmol} \mathrm{m}^{-3}\right)$ of submicrometre particulate phase $\mathrm{K}_{n s \mathrm{~s} n \mathrm{r}}^{+}, \mathrm{MSA}, \mathrm{nss}-\mathrm{SO}_{4}^{2-}, \mathrm{NH}_{4}^{+}$ and $\mathrm{Na}^{+}$and by number $\mathrm{CPC}\left(\mathrm{cm}^{-3}\right)$ collected during $\mathrm{OEA}-92$

\begin{tabular}{|c|c|c|c|c|c|c|c|c|}
\hline Lat. & Long. & $\begin{array}{c}\text { Julian day } \\
\text { mean }\end{array}$ & $\mathrm{nss}-\mathrm{SO}_{4}^{2-}$ & $\mathrm{K}_{\text {nssncr }}^{+}$ & MSA & $\mathrm{NH}_{4}^{+}$ & $\mathrm{Na}^{+}$ & $\mathrm{CPC}_{\text {average }}$ \\
\hline 56.09 & 5.23 & 319.493 & $<\mathrm{DL}$ & 0.008 & 4.56 & 4.37 & 0.79 & 167 \\
\hline 53.38 & 2.92 & 319.998 & $<\mathrm{DL}$ & 0.012 & MD & 4.24 & 0.45 & 238 \\
\hline 51.92 & 2.59 & 320.405 & 0.93 & 0.041 & 33.79 & 15.18 & 2.82 & 1411 \\
\hline 51.16 & 1.65 & 320.712 & $<\mathrm{DL}$ & 0.030 & 14.20 & 13.63 & $<\mathrm{DL}$ & 1847 \\
\hline 50.36 & -0.93 & 321.021 & 0.39 & 0.071 & 47.33 & 22.44 & 0.71 & 1786 \\
\hline 49.92 & -3.06 & 321.401 & $<\mathrm{DL}$ & 0.030 & 12.35 & 9.96 & 2.69 & 607 \\
\hline 49.41 & -4.02 & 321.708 & $<\mathrm{DL}$ & 0.013 & 3.41 & 2.53 & 3.82 & 577 \\
\hline 48.92 & -5.16 & 322.030 & $<\mathrm{DL}$ & 0.003 & 1.17 & 0.50 & 4.04 & 175 \\
\hline 48.88 & -5.49 & 322.405 & 0.20 & 0.003 & 1.47 & 1.03 & 7.76 & 114 \\
\hline 46.54 & -7.44 & 322.896 & $<\mathrm{DL}$ & 0.016 & 2.26 & 2.15 & 2.24 & 181 \\
\hline 45.62 & -8.10 & 323.398 & $<\mathrm{DL}$ & 0.025 & 2.02 & 4.74 & 1.74 & 221 \\
\hline 44.03 & -9.27 & 323.708 & $<\mathrm{DL}$ & 0.054 & 5.03 & 5.19 & 2.67 & 302 \\
\hline 42.19 & -10.22 & 324.042 & $<\mathrm{DL}$ & 0.039 & 3.69 & 2.85 & 1.03 & 236 \\
\hline 41.35 & -10.61 & 324.415 & 0.57 & 0.018 & 1.72 & 1.63 & 3.71 & 49 \\
\hline 40.29 & -11.08 & 324.707 & 0.13 & 0.020 & 2.29 & 1.60 & 1.16 & 86 \\
\hline 37.76 & -12.18 & 325.048 & 0.13 & 0.023 & 2.16 & 2.74 & 0.64 & 127 \\
\hline 34.56 & -13.46 & 326.021 & 0.17 & 0.044 & 18.04 & 2.65 & 1.14 & 155 \\
\hline 32.43 & -14.26 & 326.333 & 0.54 & 0.055 & 27.12 & 6.58 & 0.51 & 138 \\
\hline 30.69 & -14.92 & 326.651 & 0.48 & 0.078 & 33.82 & 15.38 & 1.56 & 596 \\
\hline 28.87 & -15.61 & 327.047 & 0.43 & 0.124 & 20.47 & 28.40 & 0.23 & 986 \\
\hline 27.99 & -15.95 & 327.354 & 0.41 & 0.089 & 50.94 & 23.64 & 2.77 & 1323 \\
\hline 26.93 & -16.31 & 327.646 & 0.79 & 0.056 & 12.77 & 7.05 & 3.24 & 1163 \\
\hline 23.71 & -17.31 & 328.146 & $<\mathrm{DL}$ & 0.008 & MD & 5.96 & 1.36 & 604 \\
\hline 22.00 & -17.79 & 328.646 & $<\mathrm{DL}$ & 0.039 & 3.13 & 5.36 & 1.21 & 678 \\
\hline 19.76 & -10.04 & 329.146 & $<\mathrm{DL}$ & 0.018 & 2.78 & 3.33 & 8.86 & 479 \\
\hline 18.02 & -18.02 & 329.653 & $<\mathrm{DL}$ & 0.019 & 3.19 & 2.52 & 8.63 & 335 \\
\hline 14.62 & -18.01 & 330.148 & $<\mathrm{DL}$ & 0.029 & 4.54 & 6.32 & 4.89 & 594 \\
\hline 12.85 & -17.96 & 330.646 & $<\mathrm{DL}$ & 0.049 & 4.82 & 5.41 & 8.86 & 770 \\
\hline 11.01 & -17.84 & 331.028 & $<\mathrm{DL}$ & 0.051 & 10.47 & 9.88 & 5.14 & 1034 \\
\hline 9.92 & -17.66 & 331.339 & 1.25 & 0.066 & 10.71 & 11.65 & 0.90 & 976 \\
\hline 8.91 & -16.99 & 331.646 & 5.69 & 0.106 & 14.22 & 10.61 & 9.13 & 1079 \\
\hline 6.95 & -15.64 & 332.030 & 9.10 & 0.106 & 12.91 & 9.07 & 4.02 & 1114 \\
\hline 5.99 & -14.96 & 332.337 & 5.58 & 0.100 & 7.18 & 9.20 & 2.09 & 902 \\
\hline 5.07 & -14.27 & 332.649 & 3.75 & 0.132 & MD & 7.24 & 11.34 & 695 \\
\hline 3.21 & -12.84 & 333.024 & 2.03 & 0.142 & 9.19 & 8.87 & 1.45 & 547 \\
\hline 2.33 & -12.13 & 333.335 & 0.23 & 0.195 & 9.14 & 10.43 & 1.25 & 451 \\
\hline 1.09 & -11.22 & 333.648 & $<\mathrm{DL}$ & 0.219 & 8.16 & 6.32 & 4.00 & 393 \\
\hline 0.17 & -10.33 & 334.024 & 1.62 & 0.137 & 5.55 & 7.29 & 0.00 & MD \\
\hline-2.24 & -8.61 & 334.523 & 1.50 & 0.136 & 6.08 & 7.44 & 0.30 & 211 \\
\hline-3.61 & -7.54 & 335.023 & 0.93 & 0.114 & 3.61 & 5.52 & 0.21 & 138 \\
\hline-4.49 & -6.84 & 335.335 & 1.13 & 0.199 & 4.18 & 8.05 & 3.45 & 141 \\
\hline-5.39 & -6.16 & 335.641 & 1.02 & 0.403 & 8.26 & 0.65 & 3.68 & 156 \\
\hline-7.27 & -4.69 & 336.019 & 0.64 & 0.561 & 13.57 & 8.43 & 2.96 & 189 \\
\hline-8.19 & -3.99 & 336.335 & 1.80 & 0.617 & 10.61 & 10.79 & 4.31 & 189 \\
\hline-9.56 & -2.92 & 336.648 & $<\mathrm{DL}$ & 0.615 & 10.55 & 7.60 & 1.96 & 96 \\
\hline-11.00 & -1.83 & 337.031 & $<\mathrm{DL}$ & 0.773 & 13.90 & 8.90 & 1.66 & MD \\
\hline-11.85 & -1.16 & 337.341 & 1.35 & 0.928 & 11.50 & 8.99 & 2.54 & 236 \\
\hline-13.25 & -0.05 & 337.646 & $<\mathrm{DL}$ & 0.819 & MD & 8.25 & 2.35 & 136 \\
\hline-14.61 & 1.02 & 338.023 & 0.25 & 1.083 & 13.65 & 9.08 & 3.42 & 236 \\
\hline-15.49 & 1.73 & 338.333 & 0.84 & 0.830 & 10.78 & 7.24 & 6.45 & 266 \\
\hline-16.39 & 2.43 & 338.644 & 0.25 & 0.793 & 9.10 & 4.27 & 5.02 & 308 \\
\hline-17.65 & 3.42 & 339.019 & $<\mathrm{DL}$ & 1.226 & 9.96 & 3.11 & 3.07 & 237 \\
\hline
\end{tabular}

Tellus 54B (2002), 4 
Table 1. Continued.

\begin{tabular}{|c|c|c|c|c|c|c|c|c|}
\hline Lat. & Long. & $\begin{array}{c}\text { Julian day } \\
\text { mean }\end{array}$ & nss-SO ${ }_{4}^{2-}$ & $\mathrm{K}_{\text {nssncr }}^{+}$ & MSA & $\mathrm{NH}_{4}^{+}$ & $\mathrm{Na}^{+}$ & $\mathrm{CPC}_{\text {average }}$ \\
\hline-18.83 & 4.36 & 339.517 & $<\mathrm{DL}$ & 1.031 & 5.85 & 2.31 & 1.60 & 132 \\
\hline-20.59 & 5.84 & 340.021 & $<\overline{D L}$ & 0.505 & 7.25 & 2.04 & 2.52 & 123 \\
\hline-21.29 & 6.42 & 340.333 & $<\mathrm{DL}$ & 0.261 & 4.01 & 1.63 & 0.87 & 72 \\
\hline-22.76 & 7.59 & 340.642 & 0.10 & 0.338 & 4.92 & 2.92 & 1.96 & 191 \\
\hline-24.13 & 8.73 & 341.021 & $<\mathrm{DL}$ & 0.297 & 4.74 & 2.27 & 0.89 & 149 \\
\hline-25.01 & 9.48 & 341.334 & $<\mathrm{DL}$ & 0.333 & 5.11 & 0.35 & 2.32 & 149 \\
\hline-25.83 & 10.18 & 341.642 & $<\mathrm{DL}$ & 0.341 & 4.37 & 2.62 & 2.39 & 142 \\
\hline-26.71 & 10.97 & 342.021 & $<\mathrm{DL}$ & 0.141 & 1.99 & 1.42 & 2.25 & 119 \\
\hline-27.99 & 12.17 & 342.333 & 0.16 & 0.127 & 1.40 & 1.88 & 1.03 & 119 \\
\hline-29.21 & 12.45 & 342.642 & 0.38 & 0.401 & 3.25 & 2.68 & 2.27 & 71 \\
\hline-30.81 & 15.00 & 343.021 & $<\mathrm{DL}$ & 0.207 & 2.79 & 2.02 & 0.46 & 81 \\
\hline-31.64 & 15.91 & 343.394 & $<\mathrm{DL}$ & 0.170 & 3.38 & 2.49 & 0.59 & 114 \\
\hline-33.30 & 17.66 & 343.749 & 0.46 & 0.158 & 1.54 & 3.03 & 2.09 & 118 \\
\hline-36.29 & 16.48 & 345.583 & $<\mathrm{DL}$ & 0.140 & 1.35 & 2.12 & 5.49 & 204 \\
\hline-37.06 & 15.83 & 345.833 & $<\mathrm{DL}$ & 0.105 & 1.46 & 2.56 & 1.23 & 58 \\
\hline-38.52 & 14.95 & 346.083 & $<\mathrm{DL}$ & 0.179 & 0.83 & 1.42 & 11.80 & 108 \\
\hline-39.04 & 14.65 & 346.335 & $<\mathrm{DL}$ & 0.156 & 1.36 & 2.02 & 0.47 & 133 \\
\hline-39.88 & 14.00 & 346.580 & $<\mathrm{DL}$ & 0.177 & 1.40 & 1.81 & 0.41 & 101 \\
\hline-40.98 & 13.04 & 346.859 & $<\mathrm{DL}$ & 0.196 & 1.31 & 1.26 & 14.68 & 120 \\
\hline-43.16 & 11.48 & 347.320 & $<\mathrm{DL}$ & 0.223 & 2.42 & 3.60 & 3.75 & 135 \\
\hline-46.96 & 9.41 & 348.588 & 0.94 & 0.335 & 1.70 & 2.49 & 1.87 & 103 \\
\hline-47.93 & 8.73 & 348.839 & $<\mathrm{DL}$ & 0.284 & 2.15 & 1.75 & 1.42 & 105 \\
\hline-48.88 & 7.93 & 349.084 & $<\mathrm{DL}$ & 0.290 & 1.78 & 3.98 & 3.39 & 119 \\
\hline-50.76 & 6.25 & 349.646 & 1.38 & 0.217 & 0.31 & 0.74 & 6.66 & 133 \\
\hline-51.56 & 5.60 & 349.833 & 0.43 & 0.414 & 1.59 & 3.38 & 4.35 & 169 \\
\hline-53.08 & 4.47 & 350.083 & 0.12 & 0.370 & 1.91 & 1.56 & 2.43 & 146 \\
\hline-54.34 & 3.25 & 350.458 & 0.90 & 0.494 & 1.06 & 1.61 & 7.49 & 137 \\
\hline-55.04 & 4.09 & 350.833 & 0.23 & 0.386 & 2.38 & 1.62 & 3.03 & 145 \\
\hline-55.84 & 5.47 & 351.084 & 0.29 & 0.193 & 1.30 & 0.61 & 2.91 & 148 \\
\hline-56.54 & 6.89 & 351.396 & $<\mathrm{DL}$ & 0.161 & 1.11 & 1.53 & 1.82 & 180 \\
\hline-57.41 & 7.10 & 351.708 & 0.71 & 0.284 & 1.17 & 1.28 & 4.90 & 187 \\
\hline-58.32 & 7.41 & 351.977 & 0.38 & 0.546 & 1.12 & 1.82 & 4.54 & 236 \\
\hline-59.66 & 7.66 & 352.226 & 0.03 & 0.276 & 1.25 & 0.60 & 3.12 & 276 \\
\hline-60.07 & 7.03 & 352.458 & MD & MD & MD & MD & $\mathrm{MD}$ & 304 \\
\hline-60.23 & 6.54 & 352.708 & 0.74 & 0.485 & 1.84 & 0.95 & 8.24 & 323 \\
\hline-60.47 & 5.97 & 352.958 & 0.29 & 0.493 & 1.88 & 1.10 & 5.56 & 274 \\
\hline-60.91 & 5.47 & 353.208 & 0.19 & 0.314 & 1.61 & 0.66 & 4.63 & 261 \\
\hline-61.94 & 5.31 & 353.458 & 0.34 & 0.866 & 2.71 & 1.94 & 10.00 & 242 \\
\hline-63.02 & 5.85 & 353.708 & 0.18 & 0.583 & 1.01 & 0.88 & 3.25 & 187 \\
\hline-64.08 & 5.81 & 353.958 & 0.94 & 0.606 & 1.45 & 0.66 & 4.92 & 231 \\
\hline-65.26 & 5.69 & 354.208 & 0.51 & 0.334 & 1.44 & 0.33 & 2.17 & 216 \\
\hline-66.24 & 4.52 & 354.458 & $<\mathrm{DL}$ & 0.312 & 1.55 & 0.27 & 1.34 & 194 \\
\hline-67.00 & 2.43 & 354.708 & 0.17 & 0.229 & 1.57 & 1.25 & 1.87 & 229 \\
\hline-67.49 & 0.99 & 354.958 & 0.70 & 0.222 & 1.59 & 1.25 & 2.79 & 270 \\
\hline-67.89 & -0.79 & 355.208 & 0.16 & 0.126 & 1.90 & 0.38 & 1.01 & 207 \\
\hline-68.24 & -2.16 & 355.521 & 0.37 & 0.136 & 1.96 & 0.42 & 1.62 & 126 \\
\hline-68.30 & -2.27 & 355.833 & 0.38 & 0.354 & 1.90 & 2.53 & 1.88 & 129 \\
\hline-69.59 & -3.42 & 356.083 & 0.26 & 0.594 & 3.09 & 3.23 & 2.26 & 194 \\
\hline-70.14 & -6.03 & 356.417 & 0.14 & 0.804 & 2.86 & 5.34 & 1.33 & 198 \\
\hline-70.94 & -12.18 & 356.792 & 0.04 & 0.062 & 1.44 & 1.77 & 1.05 & 123 \\
\hline-66.65 & 5.31 & 364.583 & 0.41 & 0.443 & 1.34 & 1.63 & 3.28 & 99 \\
\hline-65.52 & 5.79 & 364.833 & 0.51 & 1.240 & 1.99 & 3.39 & 7.03 & 166 \\
\hline-64.33 & 5.97 & 365.083 & 0.51 & 0.971 & 2.08 & 2.30 & 4.06 & 221 \\
\hline
\end{tabular}


Table 1. Continued.

\begin{tabular}{|c|c|c|c|c|c|c|c|c|}
\hline Lat. & Long. & $\begin{array}{c}\text { Julian day } \\
\text { mean }\end{array}$ & $\mathrm{nss}-\mathrm{SO}_{4}^{2-}$ & $\mathrm{K}_{\text {nssncr }}^{+}$ & MSA & $\mathrm{NH}_{4}^{+}$ & $\mathrm{Na}^{+}$ & $\mathrm{CPC}_{\text {average }}$ \\
\hline-63.22 & 6.13 & 365.333 & 0.39 & 0.714 & 1.79 & 2.99 & 5.46 & 280 \\
\hline-62.04 & 6.34 & 365.583 & 0.72 & 0.962 & 1.45 & 2.16 & 12.67 & 268 \\
\hline-60.81 & 6.57 & 365.833 & $<\mathrm{DL}$ & 0.892 & 0.94 & 3.93 & 10.99 & 169 \\
\hline-58.42 & 7.08 & 366.349 & $<\mathrm{DL}$ & 0.292 & 0.85 & 2.07 & $<\mathrm{DL}$ & 281 \\
\hline-57.42 & 7.21 & 366.599 & 0.14 & 0.279 & 1.36 & 3.11 & 0.38 & 381 \\
\hline-56.32 & 7.39 & 366.833 & 0.57 & 0.658 & 2.02 & 2.40 & $<\mathrm{DL}$ & 208 \\
\hline-54.09 & 7.62 & 367.120 & $<\mathrm{DL}$ & 0.319 & 1.00 & 1.95 & 0.89 & 74 \\
\hline-53.01 & 7.89 & 367.370 & $<\mathrm{DL}$ & 0.079 & 0.24 & 0.34 & $<\mathrm{DL}$ & 38 \\
\hline-52.01 & 8.43 & 367.583 & 0.15 & 0.289 & 0.55 & 1.53 & 0.64 & 87 \\
\hline-50.37 & 9.34 & 367.833 & 0.38 & 0.642 & 1.99 & 4.25 & 2.01 & 173 \\
\hline-49.46 & 9.91 & 368.083 & $<\mathrm{DL}$ & 0.633 & 2.27 & 4.09 & 2.88 & 179 \\
\hline-49.22 & 10.07 & 368.333 & $<\mathrm{DL}$ & 0.186 & 0.91 & 1.64 & $<\mathrm{DL}$ & 168 \\
\hline-48.97 & 10.23 & 368.583 & $<\mathrm{DL}$ & 0.587 & 2.23 & 5.45 & 4.92 & 203 \\
\hline-48.46 & 10.52 & 368.833 & 0.29 & 0.545 & 1.60 & 4.09 & 7.00 & 318 \\
\hline-47.99 & 10.79 & 369.083 & 0.14 & 0.249 & 0.89 & 3.42 & 5.18 & 272 \\
\hline-45.88 & 12.09 & 369.339 & $<\mathrm{DL}$ & 0.459 & 1.64 & 3.51 & 3.34 & 251 \\
\hline
\end{tabular}

All values are at STP. $<$ DL, below detection limit; MD, missing data.

meridional distribution of vanadium over the Atlantic. In the two broad latitude bands for which prior vanadium data existed, the values in the marine data base of Heintzenberg et al. (2000) agree with the higher resolution of the present study within a factor of three.

The back trajectories in Fig. 1, as discussed in the previous section, show that peak A1 ( V and CPC) was dominated by air masses passing over the UK. The trajectories related to the smaller vanadium peak A2 showed no recent contact with industrial source regions and passed through frequent areas of wet scavenging. However, within $5 \mathrm{~d}$ before arrival the air masses remained in the polluted mid-latitude north Atlantic area. The air masses related to the large peak A3 (V and CPC) swept over Portugal before passing the highly trafficked waters near the entrance of the Mediterranean. The trajectories connected with peak A4 lead to the highly populated West African source region.

The broad CPC maximum between $20^{\circ} \mathrm{N}$ and the equator cannot be explained by vanadium and air mass origin alone. EC concentrations supply additional source- related information. Both fossil fuel and biomass combustion generate large amounts of EC. Figure 3c shows highest EC concentrations in the southern part of the broad CPC peak south of $10^{\circ} \mathrm{N}$, which may appear unexpected in comparison to the relatively low EC concentrations with concurrent high vanadium concentrations in the mid-latitude samples around $50^{\circ} \mathrm{N}$. However, if we compare the particulate mass ratios $\mathrm{EC} / \mathrm{V}$ in the two sample regions we find good agreement with published ratios from the European coastal region (Neusüß et al., 2000) and from a biomass-burning region (Artaxo et al., 1994). Potassium is a more specific tracer of biomass burning. In Fig. 3c, it clearly delineates the samples which were affected by biomass burning. A quality check of the non-sea salt non-crustal potassium $\left(\mathrm{K}_{\mathrm{nssncr}}\right)$ values of the present study with the marine aerosol data base is not possible because the annual average Atlantic data are strongly biased towards high crustal calcium values in the African plume masking any continental non-crustal potassium signal. The present study took place during the annual minimum of desert dust storms (Herman et al., 1997), thus allowing the detection of biomass-related potassium signals.

The crustal tracer iron, depicted in Fig. 3b, clearly shows the transect of the ship through the broad Saharan plume between $27^{\circ} \mathrm{N}$ and the equator and peaking around $15^{\circ} \mathrm{N}$. In the area south of $10^{\circ} \mathrm{N}$ the source region of the crustal 
Table 2. Concentration ( $\mathrm{nmol}^{-3}$ ) of submicrometre particulate phase crustal elements vanadium ( $\left.V_{n c r}\right)$ and elemental carbon $\left(E C_{n c r}\right.$ ) collected during OEA-92

\begin{tabular}{|c|c|c|c|c|c|c|c|c|c|c|c|}
\hline Lat. & Long. & $\begin{array}{c}\text { Julian day } \\
\text { mean }\end{array}$ & nss-Ca & $\mathrm{Si}$ & $\mathrm{Al}$ & $\mathrm{Fe}$ & $\mathrm{V}_{\text {ncr }}$ & Lat. & Long. & $\begin{array}{c}\text { Julian day } \\
\text { mean }\end{array}$ & $\mathrm{EC}_{\mathrm{ncr}}$ \\
\hline 55.24 & 4.51 & 319.714 & 0.02 & $<\mathrm{DL}$ & $<\mathrm{DL}$ & $<\mathrm{DL}$ & $<\mathrm{DL}$ & 55.24 & 4.51 & 319.714 & 1.94 \\
\hline 50.36 & -0.93 & 320.719 & 0.05 & 0.22 & $<\mathrm{DL}$ & 0.15 & 0.05 & 50.36 & -0.93 & 320.719 & 61.42 \\
\hline 48.92 & -5.16 & 321.722 & 0.15 & $<\mathrm{DL}$ & $<\mathrm{DL}$ & 0.04 & 0.01 & 48.92 & -5.16 & 321.722 & 6.10 \\
\hline 46.54 & -7.44 & 322.719 & 0.07 & $<\mathrm{DL}$ & $<\mathrm{DL}$ & $<\mathrm{DL}$ & $<\mathrm{DL}$ & 46.54 & -7.44 & 322.719 & 2.17 \\
\hline 42.19 & -10.22 & 323.731 & 0.06 & $<\mathrm{DL}$ & $<\mathrm{DL}$ & $<\mathrm{DL}$ & 0.01 & 42.19 & -10.22 & 323.731 & 2.53 \\
\hline 37.76 & -12.18 & 324.757 & 0.02 & $<\mathrm{DL}$ & $<\mathrm{DL}$ & $<\mathrm{DL}$ & 0.00 & 37.76 & -12.18 & 324.757 & 2.10 \\
\hline 35.19 & -13.16 & 325.548 & MD & MD & MD & MD & MD & 30.34 & -15.06 & 326.339 & 7.28 \\
\hline 30.34 & -15.06 & 326.339 & 0.02 & $<\mathrm{DL}$ & $<\mathrm{DL}$ & $<\mathrm{DL}$ & 0.03 & 26.39 & -16.46 & 327.339 & 14.96 \\
\hline 26.39 & -16.46 & 327.339 & 0.14 & 0.60 & $<\mathrm{DL}$ & 0.10 & 0.06 & 19.14 & -18.04 & 328.651 & $<\mathrm{DL}$ \\
\hline 19.76 & -10.04 & 328.646 & 4.29 & 39.01 & 14.53 & 5.95 & 0.02 & 12.85 & -17.96 & 330.153 & $<\mathrm{DL}$ \\
\hline 12.85 & -17.96 & 330.153 & 6.80 & 71.25 & 28.22 & 11.01 & 0.01 & 8.33 & -16.62 & 331.340 & 83.70 \\
\hline 9.33 & -16.60 & 331.335 & 3.11 & 55.79 & 18.62 & 7.77 & 0.06 & 5.99 & -14.96 & 332.155 & 242.18 \\
\hline 5.99 & -14.96 & 332.151 & 1.48 & 27.22 & 10.50 & 3.27 & 0.00 & 4.60 & -13.92 & 332.651 & 158.52 \\
\hline 5.07 & -14.27 & 332.644 & 2.17 & 40.64 & 10.24 & 4.75 & 0.00 & 1.09 & -11.22 & 333.339 & 35.86 \\
\hline 1.09 & -11.22 & 333.335 & 1.32 & 25.93 & 7.72 & 3.06 & 0.00 & -2.24 & -8.61 & 334.340 & 27.90 \\
\hline-1.24 & -8.51 & 334.337 & 0.05 & 1.10 & 0.33 & 0.16 & 0.00 & -5.84 & -5.80 & 335.335 & 45.24 \\
\hline-5.39 & -6.16 & 335.330 & 0.03 & 0.33 & $<\mathrm{DL}$ & 0.06 & 0.00 & -9.56 & -2.92 & 336.335 & 17.48 \\
\hline-9.56 & -2.92 & 336.332 & 0.05 & 0.32 & $<\mathrm{DL}$ & 0.05 & 0.00 & -13.25 & -0.05 & 337.340 & 3.09 \\
\hline-13.25 & -0.05 & 337.337 & 0.06 & 0.26 & $<\mathrm{DL}$ & 0.04 & 0.01 & -16.83 & 2.77 & 338.337 & 0.10 \\
\hline-16.39 & 2.43 & 338.333 & 0.08 & 0.24 & $<\mathrm{DL}$ & 0.03 & 0.01 & -19.30 & 4.73 & 339.333 & $<\mathrm{DL}$ \\
\hline-18.83 & 4.36 & 339.330 & 0.05 & $<\mathrm{DL}$ & $<\mathrm{DL}$ & $<\mathrm{DL}$ & $<\mathrm{DL}$ & -22.76 & 7.59 & 340.333 & $<\mathrm{DL}$ \\
\hline-22.33 & 7.25 & 340.330 & 0.02 & $<\mathrm{DL}$ & $<\mathrm{DL}$ & $<\mathrm{DL}$ & $<\mathrm{DL}$ & -26.29 & 10.57 & 341.333 & $<\mathrm{DL}$ \\
\hline-25.83 & 10.18 & 341.330 & 0.13 & $<\mathrm{DL}$ & $<\mathrm{DL}$ & $<\mathrm{DL}$ & $<\mathrm{DL}$ & -29.59 & 13.88 & 342.333 & 0.02 \\
\hline-29.21 & 12.45 & 342.330 & 0.01 & $<\mathrm{DL}$ & $<\mathrm{DL}$ & $<\mathrm{DL}$ & $<\mathrm{DL}$ & -35.50 & 16.97 & 344.146 & 0.06 \\
\hline-33.30 & 17.66 & 343.396 & 0.01 & $<\mathrm{DL}$ & $<\mathrm{DL}$ & $<\mathrm{DL}$ & $<\mathrm{DL}$ & -39.04 & 14.65 & 345.958 & $<\mathrm{DL}$ \\
\hline-39.04 & 14.65 & 345.958 & 0.02 & $<\mathrm{DL}$ & $<\mathrm{DL}$ & 0.02 & $<\mathrm{DL}$ & -53.56 & 4.07 & 348.484 & $<\mathrm{DL}$ \\
\hline-46.48 & 9.76 & 347.543 & $<\mathrm{DL}$ & $<\mathrm{DL}$ & $<\mathrm{DL}$ & $<\mathrm{DL}$ & $<\mathrm{DL}$ & -60.23 & 6.54 & 351.672 & 0.42 \\
\hline-48.88 & 7.93 & 348.958 & 0.02 & $<\mathrm{DL}$ & $<\mathrm{DL}$ & $<\mathrm{DL}$ & $<\mathrm{DL}$ & -67.00 & 2.43 & 353.840 & 0.33 \\
\hline-54.34 & 3.25 & 350.208 & 0.05 & $<\mathrm{DL}$ & $<\mathrm{DL}$ & $<\mathrm{DL}$ & $<\mathrm{DL}$ & -70.94 & -12.18 & 355.903 & 0.51 \\
\hline-57.97 & 7.02 & 351.273 & 0.04 & $<\mathrm{DL}$ & $<\mathrm{DL}$ & $<\mathrm{DL}$ & $<\mathrm{DL}$ & -57.42 & 7.21 & 365.583 & 0.76 \\
\hline-60.23 & 6.54 & 352.333 & 0.05 & $<\mathrm{DL}$ & $<\mathrm{DL}$ & $<\mathrm{DL}$ & $<\mathrm{DL}$ & -48.97 & 10.23 & 367.708 & 0.59 \\
\hline-63.02 & 5.85 & 353.333 & 0.08 & $<\mathrm{DL}$ & $<\mathrm{DL}$ & $<\mathrm{DL}$ & $<\mathrm{DL}$ & -45.88 & 12.09 & 369.089 & $<\mathrm{DL}$ \\
\hline-67.00 & 2.43 & 354.340 & 0.04 & $<\mathrm{DL}$ & $<\mathrm{DL}$ & $<\mathrm{DL}$ & $<\mathrm{DL}$ & & & & \\
\hline-68.62 & -2.46 & 355.403 & 0.01 & $<\mathrm{DL}$ & $<\mathrm{DL}$ & $<\mathrm{DL}$ & $<\mathrm{DL}$ & & & & \\
\hline-70.94 & -12.18 & 356.458 & 0.01 & $<\mathrm{DL}$ & $<\mathrm{DL}$ & $<\mathrm{DL}$ & $<\mathrm{DL}$ & & & & \\
\hline-63.22 & 6.13 & 364.958 & 0.04 & $<\mathrm{DL}$ & $<\mathrm{DL}$ & $<\mathrm{DL}$ & $<\mathrm{DL}$ & & & & \\
\hline-57.42 & 7.21 & 366.083 & 0.02 & $<\mathrm{DL}$ & $<\mathrm{DL}$ & $<\mathrm{DL}$ & $<\mathrm{DL}$ & & & & \\
\hline-53.01 & 7.89 & 367.208 & $<\mathrm{DL}$ & $<\mathrm{DL}$ & $<\mathrm{DL}$ & $<\mathrm{DL}$ & $<\mathrm{DL}$ & & & & \\
\hline-48.97 & 10.23 & 368.208 & 0.03 & $<\mathrm{DL}$ & $<\mathrm{DL}$ & $<\mathrm{DL}$ & $<\mathrm{DL}$ & & & & \\
\hline-45.88 & 12.09 & 369.089 & 0.05 & $<\mathrm{DL}$ & $<\mathrm{DL}$ & $<\mathrm{DL}$ & $<\mathrm{DL}$ & & & & \\
\hline
\end{tabular}

All values are at STP. $<$ DL, below detection limit; MD, missing data.

plume coincides with the West African region of biomass burning at this time of the year (cf. the EC signal in Fig. 3c). Satellite data (Herman et al., 1997) of this time of the year (TOMS) confirm the geographic position of this mixed plume. The seasonal variability of plume strength as derived from the TOMS data explains why the iron levels as measured during the present study are substan- tially lower than the annual average value in the $0^{\circ}-15^{\circ} \mathrm{N}$ bin of the marine aerosol data base.

\subsection{Marine biogenic components}

In the region north of $20^{\circ} \mathrm{S}$ non-sea salt sulfate concentrations in the samples confirm the source identifications based on V and EC and CPC. The 


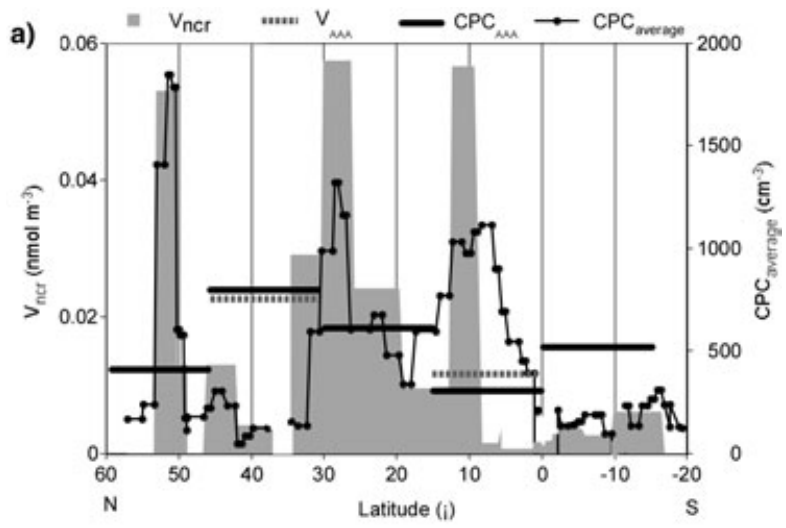

b)

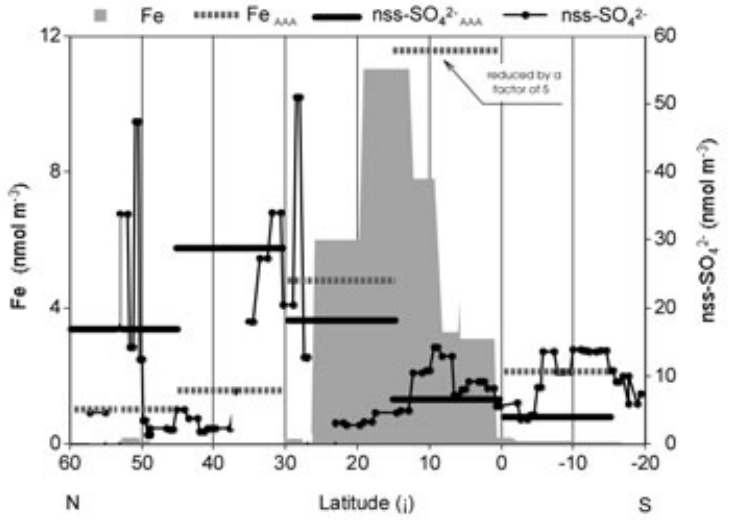

c)

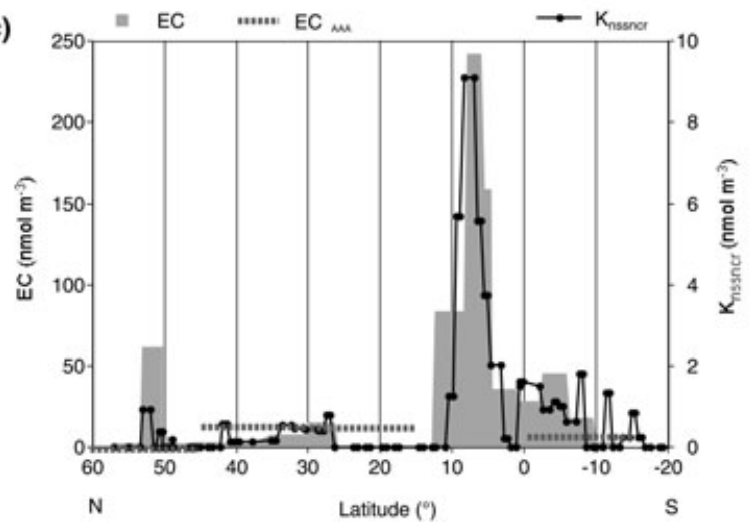

Fig. 3. (a) Latitudinal distribution of non-crustal vanadium $\left(\mathrm{V}_{\text {ncr }}\right)$ in $\mathrm{nmol} \mathrm{m}^{-3}$ and particle number concentrations $>15 \mathrm{~nm}$ diameter (CPC) in $\mathrm{cm}^{-3}$ between $60^{\circ} \mathrm{N}$ and $20^{\circ} \mathrm{S}$. For comparison annual average Atlantic (AAA) values in $15^{\circ}$ latitude and $75^{\circ} \mathrm{W}$ to $20^{\circ} \mathrm{E}$ longitude bins are shown as thick horizontal bars. Missing bars indicate missing data prior to the present study in the aerosol data base compiled by Heintzenberg et al. (2000). (b) As (a) but for iron $(\mathrm{Fe})$ and non-sea-salt sulfate (nss- $\mathrm{SO}_{4}^{2-}$ ). (c) As (a) but for elemental carbon (EC) and non-sea-salt, non-crustal potassium $\left(\mathrm{K}_{\mathrm{nssncr}}\right)$. 
absolute values are in good agreement with corresponding annual average Atlantic values of nss- $\mathrm{SO}_{4}^{2-}$. South of the equator (cf. Fig. 4), in upwelling regions with high marine primary productivity, the influence of biogenic sulfur sources on sample composition increased strongly. This hemispheric distribution of biogenic sulfur components corresponds to the seasonal distribution of marine productivity with its maximum in the austral summer.

The most specific analyzed particulate biogenic aerosol component is the oxidation product of the microbial precursor dimethyl sulfide: methane sulfonic acid. Figure $4 \mathrm{~b}$ shows the latitudinal distribution of particulate MSA south of the equator. Two areas of high MSA concentrations were identified with peaks at $15^{\circ} \mathrm{S}(\mathrm{MSA} 1)$ and $\approx 65^{\circ} \mathrm{S}$
(MSA2) with a broad minimum in between. RRS Bransfield passed this latitude region six weeks earlier (Davison et al., 1996a), however some $30^{\circ}$ to the west. This may explain why no elevated concentrations were observed at the latitudes of MSA1 then. Latitudes of the subsequent minimum were not covered by Davison et al. The samples of MSA2 were collected in partly ice-covered waters, which are characterized by intense marine biological activity in austral spring (Bürgermeister et al., 1990). During the same time period as the present study Davison et al. found even higher MSA concentrations in the region of MSA2, which we explain by the fact that their samples also included supermicrometre particles, which can carry as much as $50 \%$ of total MSA (Ayers et al., 1991). South of $30^{\circ} \mathrm{S}$, annual average Atlantic
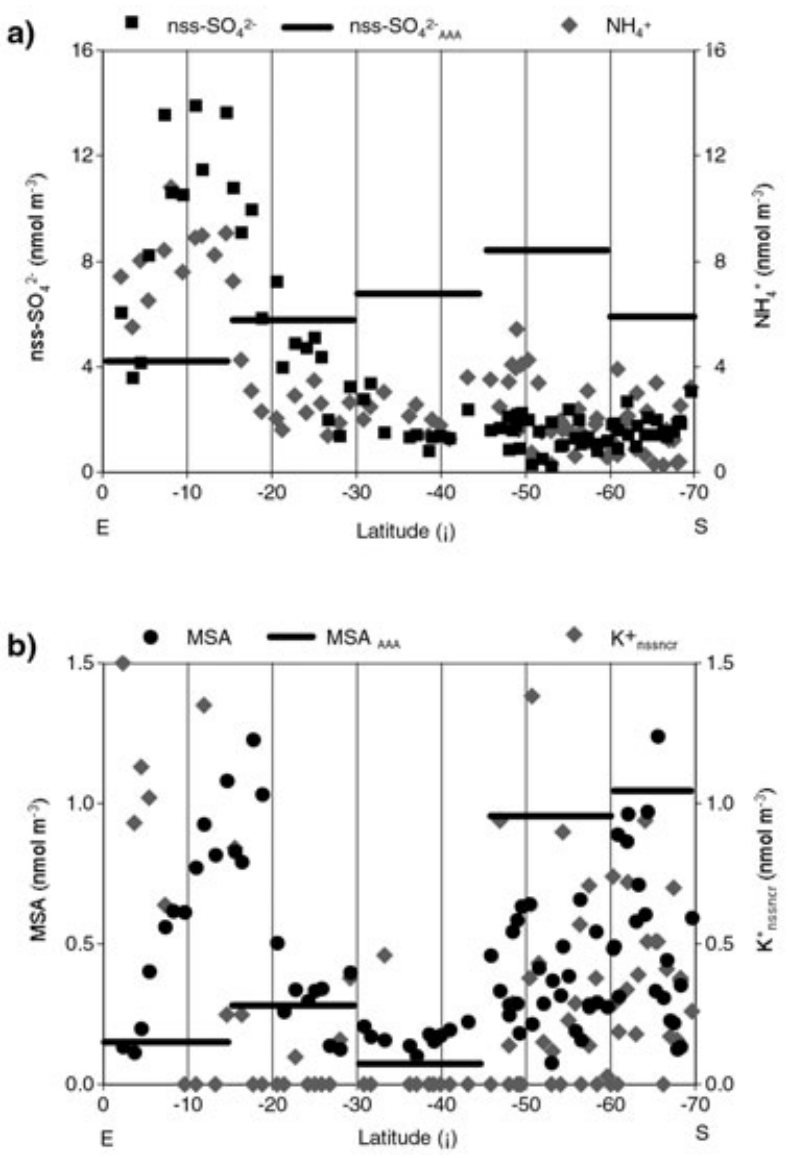

Fig. 4. (a) Latitudinal distribution of MSA in $\mathrm{nmol} \mathrm{m}^{-3}$ south of the equator. (b) As (a) but for non-sea-salt sulfate (nss- $\mathrm{SO}_{4}^{2-}$ ) and ammonium $\left(\mathrm{NH}_{4}^{+}\right)$. 
nss- $\mathrm{SO}_{4}^{2-}$ levels are significantly higher than corresponding concentrations of the present study. It is suspected that the lack of contamination control in many ship-based aerosol experiments and the inclusion of data from island and coastal stations in the data base may have led to some contributions from anthropogenic nss- $\mathrm{SO}_{4}^{2-}$.

Only in MSA1 do the two components MSA and nss- $\mathrm{SO}_{4}^{2-}$ show a spatial co-variation. There are two possible interpretations of this difference between MSA1 and MSA2: (a) MSA1 can be influenced by non-marine nss- $\mathrm{SO}_{4}^{2-}$, (b) the biogenic MSA-to-nss- $\mathrm{SO}_{4}^{2-}$ ratio is latitude (or temperature) dependent.

To quantify the biogenic components of the submicrometre aerosol, related to the atmospheric natural sulfur cycle, we went through air mass identification for each of the measured quantities. The following filtering criteria were used:

(1) Samples collected in air influenced by anthropogenic sources were omitted from the selection. Elevated concentrations of elemental carbon (Leck and Persson, 1996) were used as a tracer for combustion sources of sulfur.

(2) Samples taken in air that subsided from the free troposphere (FT) into the MBL as indicated by the trajectories were removed.

(3) Samples in which there was fog, rain, or snowfall during more than $75 \%$ of the individual sampling time were omitted from the selection, as they were likely to represent only the interstitial aerosol. Leck and Persson (1996) estimated that in remote marine areas on average $35 \%$ of the aerosol sub-micrometre particulate mass is in the drops during fog episodes.

In Table 3 we have tabulated the 25th, 50th, and 75 th percentile values of the remaining samples, about $65 \%$ of total, of particulate phase nss- $\mathrm{SO}_{4}^{2-}, \mathrm{NH}_{4}^{+}, \mathrm{MSA}, \mathrm{K}_{\mathrm{nssncr}}^{+}, \mathrm{Na}^{+}, \mathrm{EC}$, and by number $\mathrm{CPC}\left(\mathrm{cm}^{-3}\right)$. For a comparison the statistics for the total number of samples collected was included. Because of the large span of the data we have included maximum and minimum values as a further indication of the observed variability. Most of the excluded samples were taken in the Northern Hemisphere and down to $15^{\circ} \mathrm{S}$. As a result about half of MSA1 remained in the data set as biogenic. Compared to the region between MSA1 and MSA2, the excluded part of MSA1 also exhibited elevated potassium concentrations (cf. Fig. 4b), which we attribute to continental biomass burning sources. In MSA2, on the other hand, the elevated potassium concentrations are explained by material from degraded phytoplankton as found in the Arctic by Leck et al. (2002) and by Saxena (1983) in the Antarctic region of the present study. Wind-generated bubbles at the sea surface eject drops of sodium-containing sea water, which scavenge degraded organic matter enriched in potassium. This process explains the concurrent occurrence of sea salt and elevated potassium concentrations south of $50^{\circ} \mathrm{S}$ as discussed in the following section.

The molecular composition of the biogenic sulfur south of $15^{\circ}$ can be estimated from the molar ratio $\mathrm{NH} 4 / \mathrm{nss}^{-} \mathrm{SO}_{4}^{2-}$, which on average has the value of 0.97 , indicating a partly neutralized acidic aerosol as found in other remote marine regions by, e.g., Covert (1988).

A key feature of the molar ratio $\mathrm{MSA} / \mathrm{nss}^{-\mathrm{SO}_{4}^{2-}}$ in biogenic marine aerosols that should be explained by any DMS oxidation scheme is the strong latitudinal dependence, probably derived from temperature dependencies in the oxidation kinetics (Ayers et al., 1996). The molar $\mathrm{MSA} / \mathrm{nss}^{-\mathrm{SO}_{4}^{2-}}$ ratio has been observed in many studies to be highly variable, but to have an underlying trend towards a higher ratio at higher latitudes, as conveniently summarized by Bates et al. (1992). The existence of such a trend was also confirmed by the present study as depicted in Fig. 5, which shows this ratio as a function of latitude for the data set after filtering according to our three criteria. In this filtered data set, the molar ratio $\mathrm{MSA} / \mathrm{nss}_{-} \mathrm{SO}_{4}^{2-}$ ranged between 1 and close to $80 \%$. Both studies cited above and the present results suggest a ratio of about $5 \%$ at $\geqslant 298 \mathrm{~K}$, rising to around $35 \%$ at $277 \mathrm{~K}$. Thus, the temperature dependence of the molar ratio $\mathrm{MSA} / \mathrm{nss}^{-\mathrm{SO}_{4}^{2-}}$ found in the present study provides an explanation for the measured decreasing importance of $\mathrm{nss}-\mathrm{SO}_{4}^{2-}$ relative to MSA with increasing southern latitude.

\section{Synthesis}

The chemical results of the individual samples as discussed above were synthesized into regional average analyzed mass fractions according to the air mass classification developed in Section 3 and 
Table 3. Concentration ( $n m o l m^{-3}$ ) statistics for submicrometre particulate phase nss-SO $\mathrm{O}_{4}^{2-}, \mathrm{NH}_{4}^{+}, \mathrm{MSA}$, $\mathrm{K}_{\mathrm{nssncr}}^{+}, \mathrm{Na}^{+}, E C$, and by number $\mathrm{CPC}\left(\mathrm{cm}^{-3}\right)$ averaged over the FP time periods (all values are at STP)

\begin{tabular}{|c|c|c|c|c|c|c|c|}
\hline & $\begin{array}{c}\mathrm{nss}^{-\mathrm{SO}_{4}^{2-}} \\
\left(\mathrm{nmol} \mathrm{m}{ }^{-3}\right)\end{array}$ & $\begin{array}{c}\mathrm{NH}_{4}^{+} \\
\left(\mathrm{nmol} \mathrm{m}^{-3}\right)\end{array}$ & $\begin{array}{c}\text { MSA } \\
\left(\mathrm{nmol} \mathrm{m}^{-3}\right)\end{array}$ & $\begin{array}{c}\mathrm{K}_{\text {nssncr }}^{+} \\
\left(\mathrm{nmol} \mathrm{m}^{-3}\right)\end{array}$ & $\begin{array}{c}\mathrm{Na}^{+} \\
\left(\mathrm{nmol} \mathrm{m}^{-3}\right)\end{array}$ & $\begin{array}{c}\mathrm{EC} \\
\left(\mathrm{nmol} \mathrm{m}^{-3}\right)\end{array}$ & $\begin{array}{c}\mathrm{CPC}_{\text {average }} \\
\left(\mathrm{cm}^{-3}\right)\end{array}$ \\
\hline & \multicolumn{7}{|c|}{ Total } \\
\hline Number of samples & 117 & 120 & 120 & 120 & 115 & 33 & 121 \\
\hline 50th percentile (median) & 2.3 & 2.7 & 0.22 & 0.42 & 2.5 & 2.8 & 190 \\
\hline 25 th percentile & 1.5 & 1.6 & 0.090 & 0.29 & 1.3 & 0.57 & 140 \\
\hline 75th percentile & 6.4 & 6.1 & 0.49 & 0.90 & 4.5 & 29 & 300 \\
\hline $\operatorname{Min}$ & 0.24 & 0.27 & 0.008 & 0.030 & 0.001 & 0.020 & 38 \\
\hline \multirow[t]{2}{*}{ Max } & 51 & 28 & 1.2 & 9.1 & 15 & 240 & 1850 \\
\hline & \multicolumn{7}{|c|}{ Marine biogenic } \\
\hline Number of samples & 77 & 77 & 77 & 77 & 73 & 21 & 77 \\
\hline 50th percentile (median) & 1.8 & 2.1 & 0.31 & 0.37 & 2.9 & 0.33 & 180 \\
\hline 25 th percentile & 1.4 & 1.4 & 0.19 & 0.18 & 1.6 & 0.050 & 120 \\
\hline 75th percentile & 2.8 & 3.2 & 0.55 & 0.51 & 5.0 & 0.51 & 240 \\
\hline Min & 0.24 & 0.27 & 0.018 & 0.028 & 0.38 & 0.020 & 38 \\
\hline Max & 14 & 9.1 & 1.2 & 1.4 & 15 & 0.76 & 770 \\
\hline
\end{tabular}

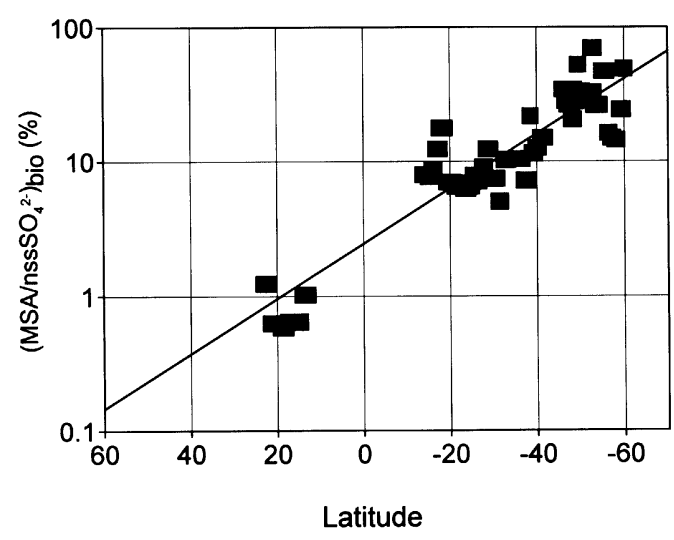

Fig. 5. The MSA-to-nss-SO ${ }_{4}^{2-}$ bio molar ratio, $\mathrm{RT}(\%)$, as a function of latitude, LAT. The displayed regression line has the form $\log (\mathrm{RT})=2.443 \times 10^{-0.02 \mathrm{LAT}},\left(r^{2}=\right.$ $0.837)$.

tabulated in Fig. 1. As a rough estimate of the total submicrometre crustal mass we multiplied the analyzed iron concentrations with the sum of abundances relative to $\mathrm{Fe}$ of other crustal elements, according to Taylor (1964). Based on sodium concentrations and relative abundances (with respect to sodium) of other seawater components, a rough estimate of total sea salt mass was calculated. For an estimate of the sum of biological components, the biological fraction of nss- $\mathrm{SO}_{4}^{2-}$ was estimated from the temperature dependence of the molar ratio $\mathrm{MSA} / \mathrm{nss}^{-} \mathrm{SO}_{4}^{2-}$ as derived from the filtered data set. The corresponding fraction of $\mathrm{NH}_{4}^{+}$bound to the biological part of nss- $\mathrm{SO}_{4}^{2-}$ was estimated with a molar ratio $\mathrm{NH} 4 / \mathrm{nss}^{-} \mathrm{SO}_{4}^{2-}($ bio $)=0.97$. The remaining fractions of $\mathrm{NH}_{4}^{+}$and nss- $\mathrm{SO}_{4}^{2-}$ combined with EC can be taken as a rough estimate of anthropogenic submicrometre aerosol components. Figure 6a collects the ensuing relative mass ratios for the 12 air mass regions and different natural and anthropogenic components. We note at this point that the lack of organic carbon analyses in the present study limits the applicability of the derived mass.

As displayed in terms of relative chemical mass fractions of the submicrometre aerosol in Fig. 6a, the two hemispheres exhibit substantial compositional differences. These two chemical regimes are separated by the strong crustal plume from the Saharan and Sahel region, which in turn exhibits a unique aerosol composition. There is a transitional zone between the dust plume and the clean southern hemispheric aerosol regime, which still exhibits influences from both crustal and combustion sources. Position of this transitional zone and relative contributions from the two source types are strongly dependent on season. Within the Saharan dust plume proper the mass contribution of sea salt is low in spite of the seasonal dust minimum experienced during the present cruise. In the southern part of the dust plume (Central Atlantic Ocean, Tropical Africa) biomass burning contributes significantly to submicrometre chem- 

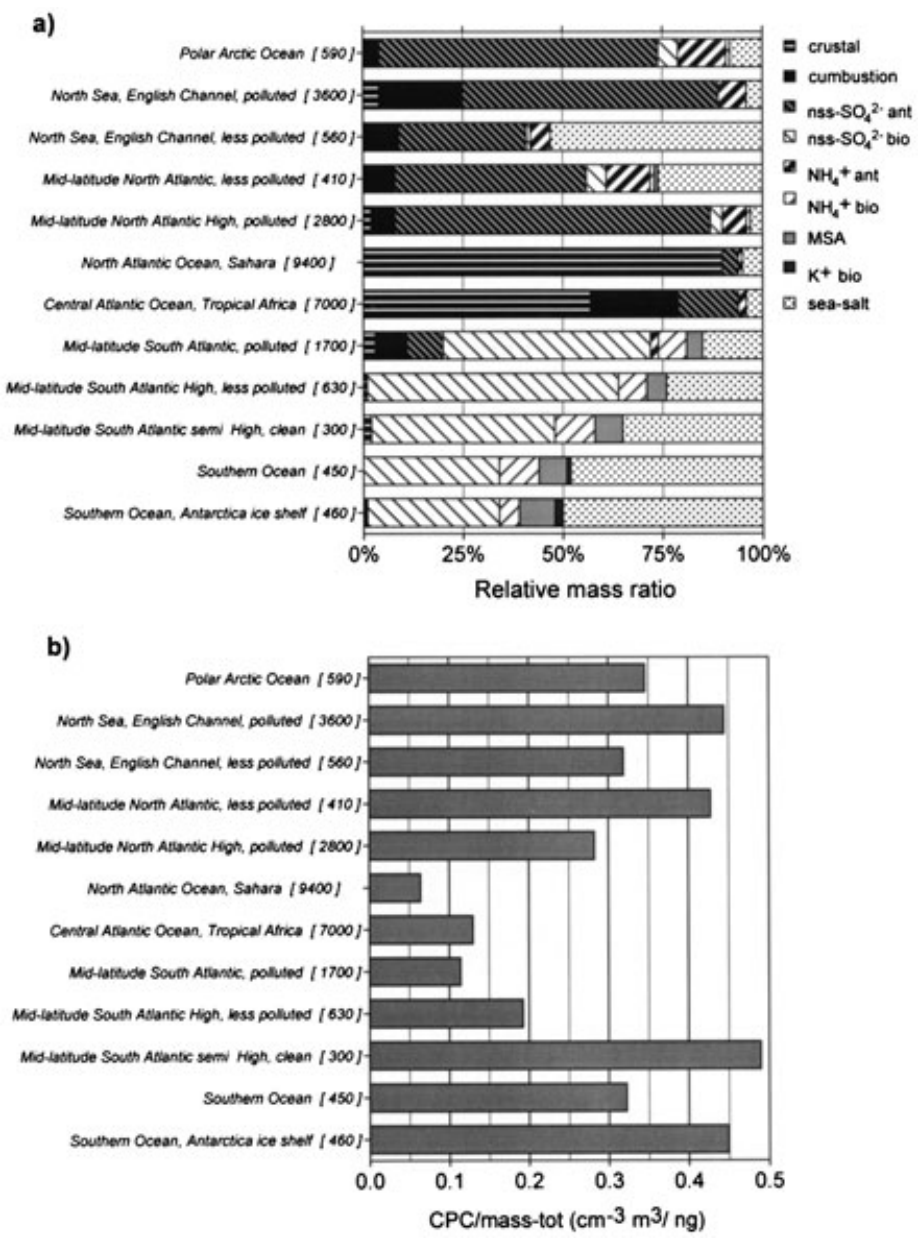

Fig. 6. (a) Relative mass fractions (\%) of analyzed and derived chemical components of the submicrometre aerosol as a function of air mass region. (b) Ratio of particle number concentrations $\geqslant 15 \mathrm{~nm}$ to analyzed mass concentrations in units of $\mathrm{cm}^{-3} \mathrm{~m}^{3} \mathrm{ng}^{-1}$. The sum of analyzed mass concentrations is given in parentheses in $\mathrm{ng} \mathrm{m}^{-3}$ after the name of the respective region.

ical mass fractions of the aerosol. As expected, and in agreement with Heintzenberg et al. (2000), sea salt exceeds $50 \%$ of the analyzed mass only in northern and southern mid-latitudes, which exhibit high wind speeds $\left(15-20 \mathrm{~m} \mathrm{~s}^{-1}\right.$ in the present study). In spite of low wind speeds (below $10 \mathrm{~m} \mathrm{~s}^{-1}$ ) the region close to the Antarctic ice shelf also shows high sea salt mass contributions, which are due to the bubble bursting mechanism. This is due to the fact that the remaining regional aerosol sources contribute sulfur and nitrogen components only to the submicrometre mass (aside from unanalyzed carbonaceous compon- ents). As mentioned in Section 4.2 the bubble mechanism is responsible for both biogenic potassium and the relatively high levels of sea salt, which show up in the Southern Ocean and close to the Antarctic ice shelf. Most likely, the bubble process contributes significantly to the unanalyzed organic aerosol fraction.

With the exception of the crustal plume, nonsea salt sulfur is the most abundant element in all sampled low sea salt regions. In the three northern hemispheric ones of these regions, all influenced by the European plume, sulfate contributes more than two thirds of the analyzed mass. The combus- 
tion origin of this sulfate is reflected in the corresponding high concentrations of elemental carbon. The same mass proportions apply in the clean southern hemisphere. However, the biogenic sulfur $\left[\mathrm{nss}-\mathrm{SO}_{4}^{2-}\right.$ (bio) + MSA] constitutes the high mass contributions in Fig. 6a.

In the above section the regional contribution of the components to the analyzed mass was discussed. Analyzed mass concentrations themselves also exhibit considerable regional (or air mass) variability with high values in the crustal plume (cf. Fig. 6a). Next highest values were observed in the European plume. Less polluted samples in both hemispheres lie more than one order of magnitude below the two continental plumes.

Global chemical transport models succeed in simulating mass concentrations of sulfate and other aerosol components to some extent. Consequently, related direct climate forcing by anthropogenic aerosols is also simulated rather well. However, indirect climate forcing by anthropogenic aerosols is more closely related to particle number and number of cloud droplets, which require the incorporation of aerosol/cloud dynamics into the numerical models. Both model resolution and process understanding severely limit today's climate general circulation models. Until further refinements of the models, empirical relationships between modeled aerosol parameters and derived climate effects will have to build on observed number and mass related aerosol data. One would expect such relationships to be more readily visible in sub-ranges of the complete size distribution.

Besides chemical information, the present study gives particle numbers in relation to analyzed mass (cf. Fig. 6b) in the submicrometre size range. In this figure, the ratio of number to total analyzed mass varies strongly with region or air mass. Smallest ratios were found in the samples affected by the African crustal plume, whereas equally high ratios were observed in the highly polluted northern and in the least polluted parts of the southern hemisphere. Thus, there is no simple relationship between the meridional distributions of particulate mass and number, even for the submicrometre size range. Even in this sub-range particle number and mass vary independently with the mass dominating crustal and sea salt components residing at the largest particle sizes.

\section{Conclusions}

During a cruise from Oslo, Norway to Antarctica and back to Cape Town, South Africa, multicomponent submicrometre aerosol data were collected, filling gaps in the period November to January and space in the existing marine aerosol database of Heintzenberg et al. (2000). Their meridional distribution exhibited large sourcerelated variabilities, which we elucidated with a detailed trajectory-based air mass analysis. Anthropogenic and crustal continental aerosol plumes from Europe and Africa clearly stand out from marine sources, which become the dominant particle sources south of $15^{\circ} \mathrm{S}$. With the help of chemical tracers such as EC, vanadium, and potassium it was possible to distinguish combustion sources from the large crustal background in the African plume. With the exception of the dust

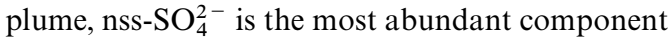
in all sampled low sea salt regions.

With the help of the combustion-related tracer EC and meteorological information, the aerosol data set was filtered to derive biologically dominated samples. From this filtered data set, a temperature (or latitude) dependence of the molar ratio $\mathrm{MSA} / \mathrm{nss}^{-\mathrm{SO}_{4}^{2-}}$ was derived, which was consistent with previous studies elsewhere. The filtered data also indicated a partly neutralized aerosol with molar ratios $\mathrm{NH}_{4}^{+} / \mathrm{nss}-\mathrm{SO}_{4}^{2-}$ close to one. The two aforementioned relationships allowed an apportionment of the observed sulfate and ammonium concentration to biogenic and anthropogenic sources over the whole meridional aerosol profile.

The observed submicrometre ratios of particle number-to-analyzed mass was explored in search of simple relationships for use in models that do not contain explicit multicomponent aerosol dynamics. However, there was no simple relationship between the meridional distributions of particle mass and number despite the restriction to the submicrometre size range.

\section{Acknowledgements}

Special thanks go to Robert Tryzell for his collecting the aerosol samples during the cruise, Leif Bäcklin for his setting up the instruments, and Astrid Jacobsson for analyzing the Nuclepore samples. The Swedish Polar Research Secretariat 
is acknowledged for help in planning the logistics of the expedition. We are obliged to ECMWF for the use of their database, computing facilities and for the support from their staff. We thank R. McGrath for letting us use his trajectory model and for his technical support with the model. This research was made possible through a donation from the Foundation Olle Enkvist Byggmästare, Sweden.

\section{REFERENCES}

Artaxo, P., Gerab, F., Yamasoe, M. A. and Martins, J. V. 1994. Fine mode aerosol composition at three longterm atmospheric monitoring sites in the amazon basin. J. Geophys. Res. 99, D11, 22,857-22,868.

Ayers, G. P., Ivey, J. P. and Gillett, R. W. 1991. Coherence between seasonal cycles of dimethyl sulphide, methanesulphonate and sulphate in marine air. Nature 349, 404-406.

Ayers, G. P., Cainey, J. M., Granek, H. and Leck, C. 1996. Dimethylsulfide oxidation and the ratio of methanesulfonate to non sea-salt sulfate in the marine aerosol. J. Atmos. Chem. 25, 307-325.

Bates, T. S., Calhoun, J. A. and Quinn, P. K. 1992. Variations in the methanesulfonate to sulfate molar ratio in submicrometer marine aerosol particles over the South Pacific Ocean. J. Geophys. Res. 97, D9, 9859-9865.

Bürgermeister, S., Zimmermann, R. L., Georgii, H.-W., Bingemer, H. G., Kirst, G. O., Janssen, M. and Ernst, W. 1990. On the biogenic origin of dimethylsulfide: relation between chlorophyll, ATP, organismic DMSP, phytoplankton species, and DMS distribution in Atlantic surface water and atmosphere. J. Great Lakes Res. 95, 20,607-20,615.

Charlson, R. J., Langner, J., Rodhe, H., Leovy, C. B. and Warren, S. G. 1991. Perturbation of the northern hemisphere radiative balance by backscattering of anthropogenic sulfate aerosols. Tellus 43AB, 152-163.

Covert, D. S. 1988. North Pacific marine background aerosol: average ammonium to sulfate molar ratio equals 1. J. Geophys. Res. 93, D7, 8455-8458.

Davison, B., Hewitt, C. N., O’Dowd, C. D., Lowe, J. A., Smith, M. H., et al. 1996a. Dimethyl sulfide, methane sulfonic acid and physicochemical aerosol properties in Atlantic air from the United Kingdom to Halley Bay. J. Geophys. Res. 101, D17, 22,855-22,867.

Davison, B., O’Dowd, C., Hewitt, C. N., Smith, M. H., Harrison, R. M., et al. 1996b. Dimethyl sulfide and its oxidation products in the atmosphere of the Atlantic and Southern Oceans. Atmos. Environ. 30, 1895-1906.

Engardt, M. and Rodhe, H. 1993. A comparison between patterns of temperature trends and sulfate aerosol pollution. Geophys. Res. Lett. 20, 117-120.

Gillespie, J. B. and Lindberg, J. D. 1992. Ultraviolet and visible imaginary refractive index of strongly absorbing atmospheric particulate matter. Appl. Opt. 31, 2112-2115.

Hansson, H.-C., Martinsson, B. G., Swietlicki, E., Asking, L., Heintzenberg, J. and Ogren, J. A. 1986.
PIXE in complex analytical systems for atmospheric chemistry. Nucl. Instr. Meth. 22B, 235-240.

Heintzenberg, J. 1982. Size-segregated measurements of particulate elemental carbon and aerosol light absorption at remote Arctic locations. Atmos. Environ. 16, 2461-2469.

Heintzenberg, J. 1988. A processor-controlled multisample soot photometer. Aerosol Sci. Technol. 8, 227-233.

Heintzenberg, J., Covert, D. S. and Van Dingenen, R. 2000. Size distribution and chemical composition of marine aerosols: compilation and review. Tellus 52B, 1104-1122.

Herman, J. R., Bhartia, P. K., Torres, O., Hsu, C., Seftor, C. and Celarier, E. 1997. Global distribution of UV-absorbing aerosols from Nimbus 7/TOMS data, 1997. J. Geophys. Res. 102, D14, 16,911-16,922.

Johansson, T. B., Akselsson, R. and Johansson, S. A. E. 1970. X-ray analysis: elemental trace analysis at the $10^{-12}$ g level. Nucl. Instr. Meth. 84, 141-143.

Junge, C. and Jaenicke, R. 1971. New results in background aerosols studied from the Atlantic expedition of the R.V. Meteor, spring 1969. J. Aerosol Sci. 2, 305-314.

Karl, T. R., Knight, R. W., Kukla, G. and Gavin, J. 1995. Evidence for radiative effects of anthropogenic sulfate aerosols in the observed climate record. In: Aerosol forcing of climate (eds. R. J. Charlson and J. Heintzenberg), John Wiley \& Sons, New York, 363-384.

Kerker, M., Schemer, P., Cooke, D. D. and Kratohvil, J. P. 1979. Absorption index and color of colloidal hematite. J. Colloid Interface Sci. 71, 176-187.

Kiehl, J. T. and Rodhe, H. 1995. Modeling geographical and seasonal forcing due to aerosols. In: Aerosol forcing of climate (eds. R. J. Charlson and J. Heintzenberg), John Wiley \& Sons, New York, 281-296.

Kiehl, J. T., Schneider, T. L., Portmann, R. W. and Solomon, S. 1999. Climate forcing due to tropospheric and stratospheric ozone. J. Geophys. Res. 104, D24, 31,239-31,254.

Kiehl, J. T., Schneider, T. L., Rasch, P. J., Barth, M. C. and Portman, R. W. 2000. Radiative forcing due to sulfate aerosols from simulations with the NCAR community climate model (CCM3). J. Geophys. Res. 105, 1441-1457.

Langner, J. and Rodhe, H. 1991. A global threedimensional model of the tropospheric sulfur cycle. J. Atmos. Chem. 13, 225-264.

Leck, C., Norman, M., Bigg, E. K. and Hillamo, R. 2002. Chemical composition and sources of the high Arctic

Tellus 54B (2002), 4 
aerosol relevant for cloud formation. J. Geophys. Res., in press.

Leck, C. and Persson, C. 1996. Seasonal and short-term variability in dimethyl sulfide, sulfur dioxide and biogenic sulfur and sea salt aerosol particles in the Arctic marine boundary layer during summer and autumn. Tellus 48B, 272-299.

Liousse, C., Penner, J. E., Chuang, C., Walton, J. J. and Eddleman, H. 1996. A global three-dimensional model study of carbonaceous aerosols. J. Geophys. Res. 101, D14, 19,411-19,432.

McGrath, R. 1989. Trajectory models and their use in the Irish Meteorological Service. 112/89, Irish Meteorological Service, Dublin.

Neusüß, C., Weise, D., Birmili, W., Wex, H., Wiedensohler, A. and Covert, D. S. 2000. Size-segregated chemical, gravimetric and number distribution-derived mass closure of the aerosol in Sagres, Portugal during ACE-2. Tellus 52B, 169-184.

Noone, K. J. and Hansson, H.-C. 1990. Calibration of the TSI-3760 condensation nucleus counter for nonstandard operating conditions. Aerosol Sci. Technol. 13, 478-485.

Ogren, J. A. and Heintzenberg, J. 1990. Parametric aerosol sampling at low concentration levels. AA-1, Department of Meteorology, Stockholm University.

Penner, J. E. 1995. Carbonaceous aerosols influencing atmospheric radiation: black and organic carbon. In: Aerosol forcing of climate (eds. R. J. Charlson and J. Heintzenberg), John Wiley \& Sons, New York, 91-108.

Penner, J. E., Dickinson, R. E. and O'Neill, C. A. 1992 Effects of aerosol from biomass burning on the global radiation budget. Science 256, 1432-1434.

Rahn, K. A. 1976. The chemical composition of the atmospheric aerosol. Graduate School of Oceanography, University of Rhode Island, Kingston, RI, USA

Roeckner, E., Siebert, T. and Feichter, J. 1995. Climatic response to anthropogenic sulfate forcing simulated with a general circulation model. In: Aerosol forcing of climate (eds. R. J. Charlson and J. Heintzenberg), John Wiley \& Sons, New York, 349-362.

Saxena, V. K. 1983. Evidence of biogenic nuclei involvement in Antarctic coastal clouds. J. Phys. Chem. 87, 4130-4134.

Taylor, K. E. and Penner, J. E. 1994. Response of the climate system to atmospheric aerosols and greenhouse gases. Nature 369, 734-737.

Taylor, S. R. 1964. Abundance of chemical elements in the continental crust: a new table. Geochim. Cosmochim. Acta 28, 1273-1285.

Wilson, T. R. S. 1975. Salinity and major elements of seawater. In: Chemical oceanography (eds. J. P. Riley and G. Skirrow), 2nd edn. Academic Press, Orlando, FL, 365-413. 